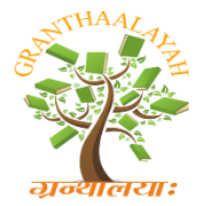

\author{
INTERNATIONAL JOURNAL OF RESEARCH - \\ GRANTHAALAYAH \\ A knowledge Repository
}

Science

\title{
DETERMINATION OF THE URANIUM CONTENT IN SOME SOIL SAMPLES FROM AJAOKUTA, KOGI STATE: NIGERIA
}

\author{
Aruwa Arome *1, Philibus Musa Gyuk ${ }^{2}$, Achor Mathias Ogwo ${ }^{1}$, Isah Suleiman ${ }^{1}$ \\ ${ }^{1}$ Department of Science Laboratory, Federal Polytechnic, Idah, Nigeria \\ ${ }^{2}$ Department of Physics, Kaduna State University, Kaduna, Nigeria
}

\begin{abstract}
This work present the Uranium (238U) content in soil samples collected in Ajaokuta from some villages was been determined. The measurement of the soil Uranium activity concentration were made using a multi-channel pulse height analyzer (Camberra series 10 plus) coupled to a $76.2 \mathrm{~mm}$ x 76.2mm NaI (TI) scintillation detector. 2.93) $\square$ The mean Uranium content in the analyzed samples was found to be $(44.26 \mathrm{~Bq} / \mathrm{kg}$ which is higher than the world mean value of $35 \mathrm{~Bq} / \mathrm{kg}$. The results were in good agreement with others for soils from region which is considered as normal or slightly high in radioactivity level.
\end{abstract}

Keywords: Uranium; Soil Samples; Ajaokuta; Gamma Ray Spectrometry.

Cite This Article: Aruwa Arome, Philibus Musa Gyuk, Achor Mathias Ogwo, and Isah Suleiman. (2019). "DETERMINATION OF THE URANIUM CONTENT IN SOME SOIL SAMPLES FROM AJAOKUTA, KOGI STATE: NIGERIA." International Journal of Research - Granthaalayah, 7(9), 252-258. https://doi.org/10.29121/granthaalayah.v7.i9.2019.608.

\section{Introduction}

Natural radioactivity occurs when a nucleus decays spontaneously without external interference. The greatest contribution to the average public radiation exposure comes from radioactive elements in the earth crust and from cosmic radiation originating in deep space. Natural sources contribute on the average more than $98 \%$ of the human radiation dose excluding medical exposure [1]. The most common of these primordial radionuclides are ${ }^{40} \mathrm{~K},{ }^{238} \mathrm{U}$ and ${ }^{232} \mathrm{Th}$ and progenies. Uranium $\left({ }^{238} \mathrm{U}\right)$ which is the heaviest chemical element of natural occurrence and can be found in food, soils, waters sediments and living organism in trace quantities. Hence different techniques are usually employed to determine small amount of Uranium among which are: mass spectrometry, neutron activation analysis, nuclear fission track registration technique and gamma spectroscopy $[2]$.

Studies on radiation levels and radionuclide distribution in the environment provide vital radiological baseline information. Such information is essential in understanding human exposure from natural and man-made sources of radiation and necessary in establishing rules and regulations 
relating to radiation protection [18]. Uranium and radium belong to the group of primordial radionuclides, as they have always been present in the earth. The radionuclides ${ }^{238} \mathrm{U},{ }^{235} \mathrm{U}$ and ${ }^{232} \mathrm{Th}$, which decay through three distinct series of radionuclides, are of great importance in the nuclear fuel cycle. Not only are they present in the human body and foodstuffs but some Uranium has been detected in a variety of foodstuffs. The highest concentrations are found in shellfish, and lower levels have been measured in fresh vegetables, cereals and fish. The average per capita intake of uranium in food has been reported to be $1.3 \mu \mathrm{g}$ /day [18] and 2 - $3 \mu \mathrm{g} /$ day [20] in the USA and $1.5 \mu \mathrm{g} /$ day in Japan [19] In a review of naturally occurring sources of radioactive contamination in food, dietary intakes of ${ }^{238} \mathrm{U}$ were found to range from 12 to $45 \mathrm{mBq} / \mathrm{day}$ in several European countries, from 11 to $60 \mathrm{mBq}$ /day in Japan (the higher values were found in uranium mining areas) and from 15 to $17 \mathrm{mBq} /$ day in the USA. The average daily dietary intake was in the order of $20 \mathrm{mBq}$, or about $4 \mu \mathrm{g}$. It was often difficult to determine whether these dietary intakes included intake from drinking-water, and it was emphasized that intake from drinkingwater has sometimes been found to be equal to intake from the diet [20] Following ingestion, uranium rapidly appears in the bloodstream [20] where it is associated primarily with the red cells [22]; a non-diffusible uranyl-albumin complex also forms in equilibrium with a diffusible ionic uranyl hydrogen carbonate complex ( $23 \mathrm{UO} \mathrm{HCO}+$ ) in the plasma [22] Because of their high affinity for phosphate, carboxyl and hydroxyl groups, uranyl compounds readily combine with proteins and nucleotides to form stable complexes [22]. Clearance from the bloodstream is also rapid, and the uranium subsequently accumulates in the kidneys and the skeleton, whereas little is found in the liver [23]. The skeleton is the major site of uranium accumulation [23]. Based on the results of studies in experimental animals, it appears that the amount of soluble uranium accumulated internally is proportional to the intake from ingestion or inhalation. It has been estimated that the total body burden of uranium in humans is $40 \mu \mathrm{g}$, with approximately $40 \%$ of this being present in the muscles, $20 \%$ in the skeleton and $10 \%, 4 \%, 1 \%$ and $0.3 \%$ in the blood, lungs, liver and kidneys, respectively [22]. Uranium is the proximate source of radium and radon in the soil and rocks. Uranium prospection through the analysis of soil, rocks, plants and water has been reported by many workers [19] [20]. Uranium, present in the earth, is transferred to water, plants, food supplements and then to human beings. Uranium accumulated in humans may have a dual effect due to its chemical and radioactive properties. High intake of uranium and its decay products may lead to harmful effects in human beings. According to an estimate [21], food contributes about $15 \%$ of ingested uranium, while drinking water contributes about $85 \%$. An exposure of about $0.1 \mathrm{mg} \cdot \mathrm{kg}-1$ of body weight of soluble natural uranium results in transient chemical damage to the kidneys [23].

Human beings have always been exposed to natural radiation, which is mainly due to the activity concentration of primordial radionuclide's ${ }^{238} \mathrm{U}\left({ }^{226} \mathrm{Ra}\right)$ series, ${ }^{232} \mathrm{Th}$ series and ${ }^{40} \mathrm{~K}$ that present in the earth's crust, in building materials and in air, water and foods and in the human body itself [1]. As these radionuclides are not uniformly distributed, the knowledge of their distribution in soil, sand and rock play an important role in radiation protection and measurement. Radionuclide's are classified into four groups according to their origins: cosmic-ray produced nuclides (such as ${ }^{7} \mathrm{Be}$ an $\mathrm{d}^{14} \mathrm{C}$ ), artificially-produced nuclides (such as ${ }^{137} \mathrm{Cs}$ and ${ }^{90} \mathrm{Sr}$ ), primordial isotopes ( $\mathrm{such}$ as ${ }^{238} \mathrm{U}$ and ${ }^{40} \mathrm{~K}$ ); and natural decay products (such as INAC 2009, Rio de Janeiro, RJ, Brazil. ${ }^{226} \mathrm{Ra}$ and ${ }^{222} \mathrm{Rn}$ ). The three naturally occurring radioactive decay chains include the ${ }^{238} \mathrm{U},{ }^{235} \mathrm{U}$, and ${ }^{232} \mathrm{Th}$, which decay through a series of radioactive elements up to stable $\mathrm{Pb}$ isotopes [16]. 
In Brazil there are about 15,000 miners employed in thorium mining. Their work consists of two activities: - the monazite mining and its processing in order to obtain rare earths chloride and thorium as a by-product, - and the mining and processing of other minerals with Th and $U$ associated to the crystal structure. This processing transforms these radionuclide's and daughters into products, by-products or waste [17].

Uranium results from radionuclide sources found in the earth's crust occurring in different types of rocks and soil and the concentration and activity of uranium in any given environment depend on factors such as the geological features of the area, weather conditions, human, economic and industrial activities [12]. Several of the elements in the decay of Uranium $\left({ }^{238} \mathrm{U}\right)$ emit beta and gamma rays, the radiation of which also form a significant portion of the external radiation field on the earth's surface [3]. Hence the presence of ${ }^{238} \mathrm{U}$ in large scale in the study area can induce its accumulation in living beings and consequently will represent a potential radiological risk to the population of this area of concern. In this way the knowledge of the ${ }^{238} \mathrm{U}$ concentrations in soils is important not only to assess the contamination level but also to understand the transference processes which have occurrence at different levels of the feed chain. People can be exposed to uranium from the environment by inhaling air and dust and ingesting water, soil and vegetation. Naturally occurring uranium poses very little radiological danger because it is present in small amounts in the environment. Uranium is not considered a human carcinogen, and genetic effects of radiation from uranium have not been observed at any level of exposure. The chemical toxicity of uranium is considered a greater health concern and has a greater potential to cause observable effects than its radioactive properties. Its toxicity depends on the route of exposure (inhaled or ingested) and the solubility of its chemical form (compounds). The primary potential health effect of high levels of uranium most soluble, and therefore readily absorbed, uranium compounds are kidney toxicants if exposure is kidney disease. Uranium exposure limits and guidelines developed by various government agencies to protect human health are based on the chemical toxicity properties of uranium, rather than its radiological properties. This is because the concentrations of uranium that would pose a chemical risk are lower and more restrictive than the concentrations that would pose a radiological risk. Exposure to uranium concentrations at or below the guidelines would result in a radiation dose below the CNSC dose limit in the Radiation Protection Regulations (1 mSv per year for members of the public).

The study area is Ajaokuta LGA located at latitude $7^{0} 33^{\prime}-7^{0} 55^{\prime}$ and longitude $6^{0} 39^{\prime}-6^{0} 65^{\prime}$ on a granite of about $1740 \mathrm{~m}$ above sea level in Kogi State in the North Central part of Nigeria. The Aim of this study is to determine the Uranium content in some soil samples collected from Ajaokuta LGA, North Central - Nigeria. The area lends itself to the rolling and milling of Iron, the Ajaokuta steel complex. The lithological formations in the area are composed of basement complex biotite granite, sedimentary rocks and new basalt.

\section{Materials and Method}

A total of 20 surface soil samples of natural origin were collected from the 20 different locations at the same depth level of 0 to $7 \mathrm{~cm}$ around Ajaokuta LGA. The samples were collected from 10 villages with two sample collected from a village at 2kilometer square apart and these points of collection were marked out using (GPS). Samples are obtained by clearing the surface vegetation and removing dead organic matter from the surface of the location and then taking a core sample 
from it from a depth of $7 \mathrm{~cm}$, sample mass varied from 1.2 to $1.6 \mathrm{~kg}$. At the collection point the soil sample was wrapped in black plastic bag and again double bagged to avoid cross contamination of the samples then taken to the laboratory. All soil samples were individually allowed to dry for 72 hours under laboratory temperature of about $27^{\circ} \mathrm{C}$ and relative humidity of about $70 \%$ [4]. Each dried soil sample was grinded and sieved using a $2 \mathrm{~mm}$ mesh screen. The large particles were disposed off and the meshed soil samples were stored in plastic containers of specific dimensions for four weeks to allow time for secular equilibrium for ${ }^{238} \mathrm{U}$ and its corresponding progenies. The plastic container of fixed geometry used was ensured air-tight by using an epoxy glue to seal samples.

About $100 \mathrm{~g}$ each of meshed soil sample was then transferred to a $100 \mathrm{~cm}^{3}$ capacity aluminum container and analyzed for gamma activity immediately.

The gamma-ray analysis was done on a very sensitive gamma spectroscopic system which consists of a $76.2 \mathrm{~cm} \times 76.2 \mathrm{~cm} \mathrm{NaI}$ (TI) scintillation detector coupled to a Camberra series 10 plus multichannel analyzer (MCA). The detector has a resolution of about $7.4 \%$ at the $662 \mathrm{keV}$ line for $137 \mathrm{Cs}$ which is good enough for distinguishing gamma-ray energies of the radionuclide being measure [5]. The detector was placed in a 5cmthick lead shield to reduce the effects of natural background radiation [6], [7]).The gamma ray spectrometry located at Centre for Energy Research and Training University of Nigeria Nsukka, Nigeria was employed in the determination of activity concentration of the uranium $\left({ }^{238} \mathrm{U}\right)$. The soil samples were mounted on the surface of the scintillation detector and each counted for 21600 seconds in reproducible sample detector geometry. A computer based multichannel analyzer system with an ACCUSPEC program (model 2007p) was used for the data acquisition analysis of gamma spectra. The gamma transition of energy of $1765 \mathrm{kev}$ (due to $214 \mathrm{Bi}$ ) was used to determine the concentration of ${ }^{238} \mathrm{U}$ in the soil sample

\section{Results and Discussion}

Table 1: Activity concentration of uranium $\left({ }^{238} \mathrm{U}\right) \mathrm{Bq} / \mathrm{Kg}$

\begin{tabular}{|l|l|l|l|}
\hline Sample Location & Longitude $\left(^{(}\right) \mathbf{E}$ & Latitude $\left(^{(}\right) \mathbf{~ N}$ & $\left(^{\mathbf{2 3 8}^{\prime}} \mathbf{U}\right)$ concentration(Bq/Kg) \\
\hline Agarugu 1 & $642^{\prime}$ & $728^{\prime}$ & $33.07 \pm 3.59$ \\
\hline Agarugu 2 & $640^{\prime}$ & $730^{\prime}$ & $72.36 \pm 3.84$ \\
\hline Ajagu 1 & $641^{\prime}$ & $732^{\prime}$ & $11.54 \pm 2.62$ \\
\hline Ajagu 2 & $641^{\prime}$ & $736^{\prime}$ & $48.08 \pm 2.59$ \\
\hline Ebiya 1 & $666^{\prime}$ & $740^{\prime}$ & $20.04 \pm 4.63$ \\
\hline Ebiya 2 & $665^{\prime}$ & $742^{\prime}$ & $95.69 \pm 2.66$ \\
\hline Adogo 1 & $664^{\prime}$ & $739^{\prime}$ & $15.78 \pm 0.38$ \\
\hline Adogo 2 & $663^{\prime}$ & $737^{\prime}$ & $18.96 \pm 1.63$ \\
\hline Ajaokuta 1 & $658^{\prime}$ & $743^{\prime}$ & $45.25 \pm 3.48$ \\
\hline Ajaokuta 2 & $665^{\prime}$ & $745^{\prime}$ & $40.34 \pm 1.04$ \\
\hline Osara 1 & $639^{\prime}$ & $750^{\prime}$ & $26.07 \pm 1.85$ \\
\hline Osara 2 & $643^{\prime}$ & $752^{\prime}$ & $49 . .70 \pm 3.24$ \\
\hline Geregu 1 & $664^{\prime}$ & $754^{\prime}$ & $103.83 \pm 3.47$ \\
\hline Geregu 2 & $663^{\prime}$ & $754^{\prime}$ & $99.63 \pm 3.13$ \\
\hline Gaduma 1 & $665^{\prime}$ & $737^{\prime}$ & $44.26 \pm 3.47$ \\
\hline
\end{tabular}




\begin{tabular}{|l|l|l|l|}
\hline Gaduma 2 & $663^{\prime}$ & $738^{\prime}$ & $30.25 \pm 3.13$ \\
\hline Ogodo 1 & $638^{\prime}$ & $739^{\prime}$ & $28.15 \pm 4.59$ \\
\hline Ogodo 2 & $637^{\prime}$ & $740^{\prime}$ & $23.86 \pm 3.71$ \\
\hline Ohunene 1 & $662^{\prime}$ & $749^{\prime}$ & $46.18 \pm 0.12$ \\
\hline Ohunene 2 & $664^{\prime}$ & $755^{\prime}$ & $32.07 \pm 4.64$ \\
\hline Average & & & $44.26 \pm 2.89$ \\
\hline
\end{tabular}

Table 2: Comparison of ${ }^{238} \mathrm{U}$ activity concentration levels for soil samples from Ajaokuta LGA with values obtained in some areas.

\begin{tabular}{|l|l|l|l|}
\hline Country / Region & Sample Location & \multicolumn{1}{|c|}{$\begin{array}{c}\text { Activity } \\
\text { concentration(Bq/Kg) }\end{array}$} & Reference \\
\hline Saudi Arabia & Riyadh & $10.8-29.7$ & {$[8]$} \\
\hline Brazil/Santos & $\begin{array}{l}\text { Mangle-Area sediment and } \\
\text { soil }\end{array}$ & $38.5-226$ & {$[9]$} \\
\hline Turkey/Istanbul & Near City Area soil & $2.63-58.95$ & {$[10]$} \\
\hline India/Kangra & Country area soil & $9.26-25.4$ & {$[11]$} \\
\hline China/Xiazhuang & $\begin{array}{l}\text { Near Uranium Ore Field } \\
\text { Soil }\end{array}$ & $40.2-442$ & {$[12]$} \\
\hline Nigeria/Ibadan & Near Road Area Soil & $10.2-40.7$ & {$[13]$} \\
\hline Nigeria/Zaria & $\begin{array}{l}\text { Around Center for Energy } \\
\text { Research and Training }\end{array}$ & $4.8-11.9$ & {$[14]$} \\
\hline Nigeria/Jos & Bukuru - Jos Cement & $80.0-1240$ & {$[6]$} \\
\hline $\begin{array}{l}\text { Nigeria/Port } \\
\text { Harcourt }\end{array}$ & $\begin{array}{l}\text { Around } \\
\text { Companies }\end{array}$ & $11.54-49.90$ & {$[15]$} \\
\hline Nigeria/Ajaokuta & Ajaokuta LGA & $\begin{array}{l}\text { present } \\
\text { work }\end{array}$ \\
\hline
\end{tabular}

The uranium contents obtained in this work for all the soil samples and their mean value from Ajaokuta LGA Kogi State, Nigeria are as presented in Table 1.

Table 1, show that activity concentrations of Uranium in the soils of Agarugu 2, Ajagu 2, Ebiya 2, Ajaokuta 1, Ajaokuta 2, Osara 2, Geregu 1, Geregu 2, Gaduma 1 and Ohunene 1 all have high concentrations above the allowed limit. The highest activity concentration was recorded at Geregu 1 with a value of $103.83 \pm 3.47 \mathrm{~Bq} / \mathrm{Kg}$, this is closely followed by that recorded at Ebiya 2 with $95.69 \pm 2.66 \mathrm{~Bq} / \mathrm{Kg}$.

The average value found in this work for Uranium content in some soil samples is $44.26 \mathrm{~Bq} / \mathrm{kg}$ higher than the world mean value of $35 \mathrm{~Bq} / \mathrm{kg}{ }^{238} \mathrm{U}$ isotope [24]. The value of ${ }^{238} \mathrm{U}$ activity concentrations in the soil was found to vary from $11.54 \mathrm{~Bq} / \mathrm{kg}$ to $103.83 \mathrm{Bg} / \mathrm{kg}$. This results show that $65 \%$ of the sample locations have values above the world recommended limit of $35 \mathrm{~Bq} / \mathrm{Kg}$ which is a concern for the health of the inhabitant of the areas [24].

A comparison of the results with other results elsewhere is shown in Table 2. As can be seen in Table 2 values in this work compare suitably with the intervals found by other authors for soils which are considered as polluted or having high natural radioactivity and are slightly higher than those found for samples supposed to be not polluted or having normal radioactivity levels. 
Compared to the worldwide average concentrations in soils, the present results are higher in some places and as well lower than the world mean value. Averagely our result is higher than the world mean value with a factor of nine (9) indicating a possible accumulation of Uranium in Ajaokuta LGA which may be due to the steel rolling mills activities in the area.

\section{Conclusion}

The average ${ }^{238} \mathrm{U}$ content values obtained in this work for soil sample from Ajaokuta LGA were slightly above the worldwide value of $35 \mathrm{Bg} / \mathrm{kg}$. However 3.47 indication that 2.62 to 103.83 the results obtained vary from 11.54 while some places do not pose little or any health hazard, some places are found to have significantly high activity concentration of ${ }^{238} \mathrm{U}$ above the world mean value. The present ${ }^{238} \mathrm{U}$ content interval determined in terms of ${ }^{238} \mathrm{U}$ activity concentration for soil samples is according to the results reported in the literature compatible with those found for areas considered as normal or slightly of natural radioactivity. The data obtained in this work can therefore reliably serve as reference values for the current assessment of Uranium activity in Ajaokuta LGA.

\section{References}

[1] United Nations Scientific Committee on the Effects of Atomic Radiation (UNSCEAR) (1998). "Sources, Effects and Risks of Ionizing Radiation", United Nations, New York.

[2] Yamazaki, I. and Geraldo, L. P. (2000). Uranium Content in Phosphate fertilizers commercially produced in Brazil. Applied Radiation Isotopes, 59: 133 - 135.

[3] United Nations Scientific Committee on the Effects of Atomic Radiation (UNSCEAR) (2000). Report to the general assembly. Annex B: exposures from natural radiation sources, New York, USA.

[4] IAEA (1998). Measurement of Radionuclide's in Food and the Environment. International Atomic Energy Agency, Technical Report Series No. 295, Vienna.

[5] Ajayi I.R. and Ajayi O.S. (1999). Estimation of Absorbed Dose Rate and Collective Effective Dose Equivalent Due to Gamma Radiation from Selected Radionuclides in Soils in Ondo and Ekiti States South-West Nigeria. Radiation Protection Dosimetry, 86; 221.

[6] Ajayi, I.R - An evaluation of the equivalent dose due to natural radioactivity in the soil around the consolidated tin mine in Bukuru -Jos. Plateau State. Asian J. Radiat Res, 5(4) 203-206(2008).

[7] Farai I. P. (1998). Rn-222 Survey in Ground Water and its Assessments for Radiological Health Hazards and Seismic Monitoring in Nigeria. Unpublished Ph.D Thesis, University of Ibadan, Ibadan, Nigeria.

[8] Alaamer A.S. (2008). Assessment of Human Exposure to Natural Sources of Radiation in soil of Riyadh; Saudi Arabia Turkiol J. Eng. Env. Sci., 32, 229 - 234.

[9] A. M. S. Bianca and A.M Correa (2008) Investigation of the Uranium Content in Sediment and Soil Samples from the Santos and SAO. Vicente Estuary Regiving.

[10] Karahan, G. Bayulken, A. (2000). Assessment of Gamma Dose Rates Around Instanbul (Turkey). J. Environ. Radioactivity, 47, 213 -221.

[11] Sharma,D. K.,Kumar, A.,Kumar, M. and Singh, S. (2003). Study of Uranium, Radium and Radon Exhalation Rate in Soils Samples from Some Areas of Kangra District, Himachal Pradesh, India Using Solid-State Nuclear Track Detectors. Rad.Meas., 36, 363 -366.

[12] Yang, Y. Wu, X., Jiang, Z. (2005). Radioactivity Concentrations in Soils of The Xiazhuang Granite Area, China. Applied Radiation Isotopes, 63: 255 - 25 
[13] Jibiri,N. N., and Bankole, O. S. (2005). Soil Radioactivity and Radiation Absorbed Dose Rates at Roadsides in High-Traffic Density Areas in Ibadan Metropolis, South Western Nigeria. Radiat Prot. Dosim., 118, 453-458.

[14] Mohammad M. A., Idris, I. F., Simon, P. M. and Arabi, S.A. (2010). Distributionof Gammaemitting Radionuclides in soils around the Centre for Energy Research and Training (CERT) Ahmadu Bello University Zaria, Zaria-Nigeria Journal of America Science.

[15] Avwiri, G.O. (2005). Determination of Radionuclide Levels in Soil and Water around cement companies in PortHarcourt. Journal Applied Science Environmental Management, 9 (3) 27 - 29.

[16] I. R. Santos, W.C. Burnett and J.M. Godoy (2008). "Radionuclides as Tracers of Coastal Processes in Brazil: Review, Synthesis, and Perspectives," Brazilian Journal of Oceanography, 56(2): 115131.

[17] M.A.B.C. Menezes, C.V.S. Sabino, M.B. Franco, G.F. Kastner and E.H.M. Rossi (2003). "Instrumental Neutron Activation Analysis Establishment at CDTN, Brazil: A successful story," Journal of Radio analytical and Nuclear Chemistry, 257: 627-632.

[18] Al-Saadi, A.J., Hashim, A.S.K. and Hussein, F.M. (2014). Measurement of Radon and Uranium Concentrations in the Dates and Their Seeds of Different Regions in Karbala Governorate. Journal of Babylon University/Pure and Applied Sciences, 21: 2134-2147.

[19] Cothern, C.R. and Lappenbusch, W.L. (2014). Occurrence of Uranium in Drinking Water: US. Health Physics, 45: 89-99.

[20] Igarashi, Y., Yamakawa, A. and Ikeda, N. (2016) Plutonium and Uranium in Japanese Human Tissues. Radioisotopes, 36: 433-439.

[21] Dunn, C.E. (2015). The Bio-Geological Expression of Deeply Buried Uranium Mineralization in Saskachewan, Canada. Journal of Geochemical Exploration, 15, 437-452.

[22] Dyck, W. (2014). Application of Hydro Geochemistry to the Search of Uranium. Economic Geology Reports, 31: 489-510.

[23] Singh, J., Singh. H., Singh, S. and Bajwa, B.S. (2015) Uranium, Radium and Radon Exhalation Studies in Some Soil Samples Using Plastic Track Detectors. Indian Journal of Physics, 83: 11471153.

[24] United Nations Scientific Committee on the Effects of Atomic Radiation, UNSCEAR, (2000). "Sources, Effect, and Risks of Ionizing Radiation", Report to the general Assembly with Scientific Annexes, United Nations.

\footnotetext{
*Corresponding author.

E-mail address: aroaruwa@ gmail.com
} 